\title{
SIDOARJO PUNYA CERITA
}

\author{
Dwi Rosanti \\ Program Studi Pendidikan Guru Sekolah Dasar \\ Fakultas Keguruan dan Ilmu Pendidikan \\ Universitas Nahdlatul Ulama Sidoarjo \\ Email: Dwrsanti27@gmail.com
}

\section{Pengantar}

Kabupaten Sidoarjo adalah sebuah kota yang ada di Jawa Timur, kota ini berbatasan dengan Surabaya dan Gresik di utara, selat Madura di timur, kota Pasuruan di selatan, serta kota Mojokerto di barat.

Sidoarjo merupakan kota yang dijuluki "Kota Bersih" selain itu juga dijuluki kota Bandeng dan juga terkenal dengan makanan khas serta destinasi wisatanya. Bahkan di sidoarjo bencana alam pun bisa disulap menjadi destinasi wisata seperti Lumpur Lapindo. Dibalik kota sidoarjo yang dijuluki kota bersih dan penghasil bandeng yang melimpah, ada sejarah kota sidoarjo yang jarang diketahui pada publik.

Sejarah kabupaten Sidoarjo dimulai tepatnya pada tahun 1851 daerah Sidoarjo bernama Sidokare, bagian dari kabupaten Surabaya. Daerah Sidokare dipimpin oleh seorang R. Ng. Djojohardjo, bertempat tinggal di kampung Pucang Anom yang dibantu oleh seorang wedana yaitu Bagus Ranuwiryo yang berdiam di kampung Pangabahan.

Pada tahun 1859, berdasarkan keputusan pemerintah Hindia Belanda no. 9/1859 tanggal 31 Januari 1859 Staats blad no. 6, daerah kabupaten Surabaya dibagi menjadi dua bagian yaitu kabupaten Surabaya dan kabupaten Sidokare. Dengan demikian daerah Sidokare tidak lagi menjadi bagian dari kabupaten Surabaya dan sejak itu mulai diangkat seorang Bupati untuk memimpin kabupaten Sidokare yaitu R. Notopuro (R.T.P Tjokronegoro) berasal dari Kesepuhan, putra R.T.P Tjokronegoro Bupati Surabaya, dan bertempat tinggal di kampung Pandean (sebelah selatan Pasar Lama sekarang), beliau mendirikan Masjid di Pekauman (Masjid Abror sekarang), sedeng Alun-Alunnya pada waktu itu adalah Pasar Lama.

\section{Makanan Khas}

Sidoarjo disebut kota bandeng karena memiliki kekayaan sumber daya alam yang melimpah, seperti ikan bandeng, udang, kerang, kupang. Oleh karena itu sidoarjo memiliki makanan khas seperti otak-otak bandeng, bandeng asap, bandeng presto dan olahan bandeng lainnya. Hal ini dikarenakan wilayah sidoarjo berada di kawasan timur yang banyak dijumpai area pertambakan yang memelihara berbagai ikan terutama ikan bandeng. 
Adapun makanan khas di Sidoarjo antara lain :

1. Otak-Otak bandeng, merupakan makanan khas yang berasal dari olahan bandeng yang diolah dengan cara dagingnya diambil, lalu dicampur bumbu otak-otak dan parutan kelapa, lalu adonan ditaruh di dalam bandeng yang sudah dikupas, lalu bandeng digoreng sampai matang.

2. Lontong Kupang, merupakan hidangan sepinggan khas Sidoarjo yang terdiri dari Kupang, Lontong, dan pelengkap Lentho. Perpaduan bumbu petis, bawang putih mentah, dan kupang dengan kuah asam pedas manis yang segar, menghasilkan cita rasa unik yang lezat sehingga kupang cocok untuk dinikmati sebagai santap siang saat cuaca sedang panas.

3. Lontong Balap, merupakan hidangan makanan yang terdiri dari Lontong, tahu, tauge, dan pelengkap lentho. Perpaduan bumbu petis, dan kuah yang kecoklatan karena dicampuri kecap.

4. Sate Kerang, merupakan makanan pelengkap saat memakan hidangan lontong kupang. Sate ini terdiri dari kerang yang ditusuk dengan bambu.

5. Kerupuk Udang, merupakan kerupuk yang terbuat dari udang yang dicampur dengan adonan dan bumbu pelengkap.

\section{Destinasi Wisata}

Pengunjung destinasi wisata berasal dari dalam maupun luar kota, seperti kota tetangga (mojokerto, pasuruan, gresik, surabaya) yang ingin menikmati destinasi wisata yang ada di sidoarjo.

Banyak berbagai macam destinasi wisata yang ada disidoarjo antara lain :

1. Candi Pari di Sidoarjo

2. Candi Tawang Alun di Sedati

3. Monumen Jayandaru di pusat Alun-Alun kota Sidoarjo

4. Masjid Agung di Belakang Alun-Alun kota Sidoarjo

5. Masjid Abror di kampung Kauman jalan Gajahmada di belakang Matahari

6. Makam Mbah Ali Mas'ud di Paagerwojo

7. Delta Fishing di Prasung

8. Taman Abhirama di Sidoarjo

9. Taman Tanjoeng Puri di Lingkar Timur

10. Museum Mpu. Tantular di Sidoarjo

11. Lumpur Lapindo di Porong

12. Taman Kahuripan di Sidoarjo

13. Wisata pemancingan Kalanganyar

Selain destinasi wisata diatas, sidoarjo juga memiliki Batik Jetis yang berada di kampung tengah- tengah pusat kota Sidoarjo yaitu di daerah diponegoro pusatnya pusatnya di kampung Lemah Putro kecamatan Sidoarjo

Waktu kunjungan wisatawan biasanya pada saat hari biasa atau akhir pekan maupun hari libur nasional. Namun lebih banyak pengunjung yang lebih memanfaatkan datang ke destinasi pada saat hari weekend bersama keluarga. 


\section{Konsekuensi Lumpur Lapindo}

Pada tahun 2006 tepatnya bulan Mei Sidoarjo ditimpa musibah dan bencana, yakni terjadinya lumpur lapindo di daerah porong sidoarjo. Hal ini disebabkan oleh bocornya gas pada saat pengeboran gas bumi tersebut dilakukan atas kelalaian PT. Lapindo Brantas (Agustina, 2009). Lumpur lapindo dapat mempengaruhi kesehatan bagi mayarakat sekitar. Terutama efek pada seseorang yang menjadikan penyakit di dalam tubuh manusia.

Peristiwa ini menjadi salah satu tragedi ketika banjir lumpur panas mulai menggenangi areal persawahan, pemukiman penduduk dan kawasan industri. Hal ini wajar menginat volume lumpur diperkirakan hingga $50.000 \mathrm{~m}^{3}$ perhari (serta dengan muatan penuh 690 truk peti dikemas berukuran besar) akibatnya semburan lumpur ini mambawa dampak yang luar biasa bagi masyarakat sekitar maupun akitivitas perekonomian dijawa timur :

1. Genangan hingga setinggi 6 meter pada pemukiman

2. Total warga yang dievakuasi lebih dari 8200 jiwa

3. Rumah atau tempat tinggal yang rusak sebanyak 1683 unit

4. Areal pertanian dan perkebunan rusak hingga lebih drai 200 hektar

Diporong kecenderungan serupa muncul setelah lumpur mulai menenggelamkan sejumlah desa dan mengusir ribuan penduduk disejumlah desa itu. Potensi konflik antara penduduk dimulai sejak lumpur membenamkan tempat tinggal mereka. Mereka harus mengungsi untuk sementara waktu, namun ketika itu belum terlintas sama sekali bahwa mereka harus pergi untuk selamanya. Mereka kehilangan harta miliknya yang terbenam dalam lumpur. Ketika gelombang pertama pengungsi mulai mengalir waktu itu belum ada kejelasan siapa yang harus bertanggung jawab penanganan pasca-lumpur.

Rumah atau gedung pemerintah serta sekolahan yang rusak akibat diterjang lumpur sebanyak 1.683 unit. Dengan rincian sebagai berikut : tempat tinggal 1.810 (desa siring 142, jatirejo 480, ronokenongo 428, kedungbendo 590, besuki 170) instansi pemerintah dan gedung sekolah : (sekolah 18, kantor 2, pabrik 15, masjid dan mushalla 15 unit.)

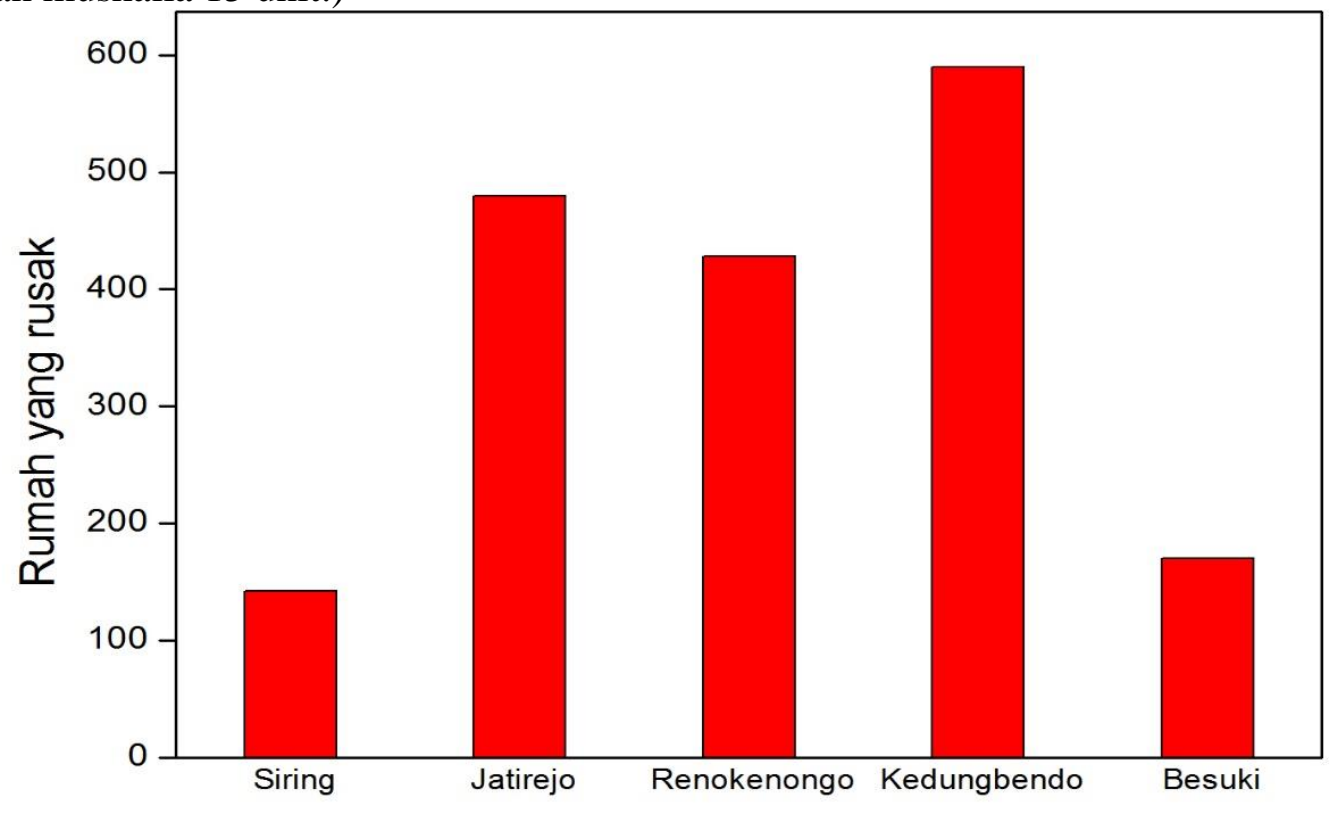




\section{PENUTUP}

Sidoarjo merupakan kota yang berada di Jawa Timur dengan berbagai cerita unik dan asal usul nya yang jarang diketahui semua publik. Sidoarjo mempunyai berbagai makanan khas dan berbagai macam cirinya serta destinasi wisata yang menarik minat para pengunjung untuk di kunjungi. Selain mempunyai makanan yang menjadi khas, sidoarjo juga mempunyai batik jetis khas sidoarjo yang siap untuk menjadi buruan para pengunjung destinasi.

Selain itu, sidoarjo juga mempunyai kisah sedih yang menimpa atas terjadinya lumpur lapindo yang sampai sekarang bisa sewaktu-waktu bocor dan jebol. Namun, dibalik kisah sedih yang dialami sidoarjo, tidak menurunkan semangat warga sidoarjo untuk menjadikan kota sidoarjo sebagai kota yang bersih, damai, dan mempunyai ciri khas yang harus dilestarikan sepanjang masa. 


\section{DAFTAR PUSTAKA}

Ivansyah, Darul. A., S. (2016) retrieved december, 24, 2018, from digilib.uinsby.ac.id/1197/7/bab\%204.pdf

Safrida, R.S. (2017) retrieved december, 24, 2018, from e-journal Unesa Boga, volume 5, No. 3, Edisi Yudisium Periode September 2017

Elika, E.P, Resnawaty R., Gutama, S., A. (2017) retrieved december, 20, 2018, from jurnal.unpad.ac.id

Yuniarti, D., Asitah, N., Nahdiyah, K., Maula, I., Munjidah, A., Sholichah, S. A., Purnomo, A., Rosyidah, E., Istiqomah, N., Anam, F., \& Achmadi, A. K. (2018, May 25). Batik Jetis Sidoarjo Sebagai Destinasi Ekskursi Impresif. http://doi.org/10.17605/OSF.IO/XRY58

Nahdiyah, K., Asitah, N., Maula, I., Munjidah, A., Yuniarti, D., Sholichah, S. A., Purnomo, A., Rosyidah, E., Achmadi, A.K., Anshori, A., Anam, F. (2018, May 27). Konsekuensi Lumpur Sidoarjo terhadap Sidoarjo dengan Perspektif Multidimensi. http://doi.org/10.17605/OSF.IO/N32BE 